https://doi.org/10.52058/2786-5274-2021-2(2)-191-200

Романенко Євген Олександрович доктор наук з державного управління, професор, Заслужений юрист України, Президент Всеукраїнської асамблеї докторів наук 3 державного управління, Проректор 3 наукової роботи, Національний авіаційний університет, проспект Любомира Гузара, 1, Київ, 03058, тел.: (063) 951-78-55, e-mail: poboss1978@gmail.com, https//orcid.org/0000-00032285-0543

Помиткіна Любов Віталіївна доктор психологічних наук, професор, завідувач кафедри авіаційної психології, Національний авіаційний університет, проспект Любомира Гузара, 1, м. Київ, 03058, тел.: (099) 138-4738, e-mail: Lyubvit@ukr.net, https://orcid.org/0000-0002-2148-9728

Жукова Ірина Віталіївна кандидат наук 3 державного управління, доцент, Виконавчий директор Президії, Всеукраїнська асамблея докторів наук 3 державного управління, Андріївський узвіз, буд.11, оф 68, м. Київ, 04070, тел.: (044) 462-55-41, e-mail: irina_pravo@ukr.net, https://orcid.org/0000-0003-4927-0610

\title{
ПСИХОЛОГІЧНІ ОСОБЛИВОСТІ ВЗАЕМОДІЇ ЛЮДИНИ З ТВАРИНАМИ
}

Анотація. Встановлено, що дослідження діяльності за участю тварин i терапії за участю тварин $€$ важливим аспектом встановлення позитивних комунікативних моделей поведінки людини. Виявлено, що позитивний емоційний настрій, який відрізняє заняття 3 дельфінами, сприяє піднесенню активності, поліпшенню настрою і загального стану пацієнтів. Гра 3 дельфіном $€$ стимулом для розвитку психомоторної сфери і різних пізнавальних процесів. Завдяки дельфінам, у пацієнта мобілізується вольова діяльність, зростає мотивація і посилюється прагнення до досягнення позитивних результатів. Тому дитина швидше і ефективніше справляється з ігровими завданнями, які ставить перед нею психотерапевт. Дельфін є стимулом для концентрації уваги дитини, поліпшення процесів пам'яті, мислення й мови.

Доведено, що вплив кішок на нервову систему і психологічний стан людей загалом позитивний, деякі інтернати, будинки для людей похилого віку, наркологічні лікарні все-таки відмовляються від таких мешканців. Пов'язано це, перш за все, з непередбачуваністю кішок, їх деякою відчуженістю («гуляє сама по собі»). Також відзначалися поодинокі випадки агресивного ставлення кішок по відношенню до людей. Тому до анімалотерапії слід залучати не абияких тварин, а лише спеціально відібраних і підготовлених. 
Зазначено, що діяльність за участю тварин може бути пасивною або активною. Як приклад першої, можна навести спостереження за тваринами в їх природному середовищі існування. При цьому хворі люди не контактують безпосередньо з тваринами, а отримують відчутну користь для здоров'я просто від їх присутності - наприклад, якщо в реабілітаційних палатах для людей похилого віку є клітини 3 птахами, то рівень депресії у них знижується. Спілкування 3 природою, «розчинення в ній» також відноситься до цієї форми спілкування з тваринами.

Відмічено, що у комунікативній системі людини тактильний канал, звичайно, не має провідного значення. Проте в певних ситуаціях саме тактильна комунікація виступає на перший план і є абсолютно необхідною для нормального розвитку психіки. Тактильна депривація дитини обумовлює дефекти розвитку емоційної i навіть когнітивної сфери, зумовлює невротичні тенденції у формуванні особистості на більш пізніх стадіях онтогенезу. Саме тому тактильна комунікація хворих дітей із собаками, повертаючи їх до витоків, дозволяє проводити досить ефективну корекцію.

Ключові слова: анімалотерапія, дельфінотерапія, фелінотерапія, зоотерапія, небезпека паразитарних захворювань.

Romanenko Yevhen Oleksandrovych, Doctor of Science in Public Administration, Professor, Honored Lawyer of Ukraine, President of the Ukrainian Assembly of Doctors of Science in public administration, Vice-Rector for Research, National Aviation University, 1 Lubomyr Husar Avenue, Kyiv, 03058 tel .: (063) 951-78-55, e-mail: poboss1978@gmail.com, https // orcid.org / 0000-0003 -2285-0543

Pomytkina Liubov Vitaliyivna Doctor of Psychological Sciences, Professor, Head of the Department of Aviation Psychology, National Aviation University, 1 Lyubomyr Husar Avenue, Kyiv, 03058, tel .: (099) 138-4738, e-mail: Lyubvit@ukr.net, https://orcid.org/0000-0002-2148-9728

Zhukova Iryna Vitaliivna Candidate of Sciences in Public Administration, Associate Professor, Executive Director of the Presidium of the Ukrainian Assembly of Doctors of Sciences in Public Administration, Andriyivskyi Uzviz, Building 11, Office 68, Kyiv, 04070, tel.: (044) 462-55-41, e-mail: irina_pravo@ukr.net, https://orcid.org/0000-0003-4927-0610

\section{PSYCHOLOGICAL FEATURES OF HUMAN INTERACTION WITH ANIMALS}

Abstract. It is established that the study of activities involving animals and therapy involving animals is an important aspect of establishing positive communicative models of human behavior. It was found that a positive emotional 
mood, which distinguishes classes with dolphins, helps to increase activity, improve mood and general condition of patients. Playing with a dolphin is a stimulus for the development of the psychomotor sphere and various cognitive processes. Thanks to dolphins, the patient's willpower is mobilized, motivation increases and the desire to achieve positive results increases. Therefore, the child copes faster and more effectively with the game tasks set before him by a psychotherapist. The dolphin is a stimulus for the child's attention, improvement of memory, thinking and speech.

It is proved that the impact of cats on the nervous system and psychological state of people is generally positive, some boarding schools, nursing homes, drug hospitals still refuse such residents. This is due primarily to the unpredictability of cats, their some alienation ("walks by itself"). There have also been isolated cases of aggressive attitudes of cats towards humans. Therefore, animal therapy should not involve any animals, but only specially selected and trained.

It is noted that activities involving animals can be passive or active. As an example of the first, we can cite the observation of animals in their natural habitat. At the same time, sick people do not come into direct contact with animals, but receive tangible health benefits simply from their presence - for example, if the rehabilitation wards for the elderly have cages with birds, the level of depression in them is reduced. Communication with nature, "dissolving in it" also refers to this form of communication with animals.

It is noted that in the human communication system, the tactile channel, of course, has no leading role. However, in certain situations it is tactile communication that comes to the fore and is absolutely necessary for the normal development of the psyche. Tactile deprivation of the child causes defects in the development of emotional and even cognitive spheres, causes neurotic tendencies in the formation of personality at later stages of ontogenesis. That is why the tactile communication of sick children with dogs, returning them to their origins, allows for a very effective correction.

Keywords: animal therapy, dolphin therapy, feline therapy, zootherapy, danger of parasitic diseases.

Постановка проблеми. В даний час анімалотерапія отримала досить широке поширення в багатьох країнах. У США, Великобританії, Канаді, Франції з'явилися організації, які займаються наданням психотерапевтичної допомоги 3 використанням тварин, називаючи свій метод «терапія за допомогою тварин» (Animal Assisted Therapy). Французька організація АНЕКАН, що використовує собак для анімалотерапії, має три центри: в Алансоні, Бордо і Клермон-Феррані. В інших країнах діють такі організації, як товариство «Дельта», Лексінгтонскій корекційний центр, анімалотерапевтіческая асоціація, «Собаки-компаньйони для незалежності» (CCI), Fidelco. Товариство «Дельта» постійно проводить дослідження в таких областях, як вплив анімалотерапії на здоров'я людей, 
використання тварин в освіті, в психотерапії і т.д. Вони пропонують курси для добровольців, які хочуть працювати зі своїми тваринами в команді фахівців, допомагають отримати спеціальні ліцензії, які дають можливість працювати 3 тваринами в таких місцях, як лікарні, будинки престарілих тощо (Програма "Тварини-партнери"). Вони використовують різних тварин, таких, як собаки, кішки, гвінейські свинки, кролики, коні, кози, віслюки, папуги, курчата і лами. У 1981 р в м Мельбурні (Австралія) в будинку для літніх людей було проведено дослідження, яке переконливо довело позитивний вплив тварин на фізіологічний та емоційний стан пацієнтів [1]. Таким чином, дослідження діяльності за участю тварин і терапії за участю тварин є важливим аспектом встановлення позитивних комунікативних моделей поведінки людини.

Аналіз останніх досліджень і публікацій. У розвиток дослідження психологічних особливостей взаємодії людини із тваринами в Україні вагомий внесок зробили такі вчені як: Л. Кряжева, Л. Хартел, Б. Левінсон, Н. Шавровська, В. Шавровська та ін. При цьому, їх дослідження в основному мають теоретичний характер та не розглядають конкретних практичних прикладів використання анімалотерапії для лікування різноманітних психологічних і психофізіологічних травм.

Мета статті. Головною метою даного наукового дослідження є вивчення психологічних особливостей взаємодії людини із тваринами.

Виклад основного матеріалу. Дельфінотерапія $\epsilon$ визнаним потужним психотерапевтичним і психокорекційних засобом [2; 3]. Основними аспектами дельфінотерапії, що впливають на пацієнта, $\epsilon$ спілкування і ігрова діяльність. Відомо, що для дітей, які мають різні психоневрологічні захворювання, порушення розвитку або пережили психотравмуючу ситуацію, характерні відчуття відчуженості, ізольованості, що супроводжуються страхами i труднощами в спілкуванні. Дельфін зі своєю природною, «анатомічною» посмішкою, дружелюбністю та інтересом до дитини сприяє формуванню контакту i закріпленню позитивних комунікативних моделей поведінки. Невербальний характер спілкування між дитиною і дельфіном полегшує завдання взаємодії для дитини, робить його природним процесом. Важливим елементом цього спілкування є тактильний контакт дитини і дельфіна. Тілесний контакт, який $\epsilon$ первинною формою взаємодії дитини 3 навколишньою дійсністю i, особливо з матір'ю, є терапевтично цінним механізмом встановлення емоційних взаємин між твариною і дитиною.

Засновником дельфінотерапії вважається доктор Девід Натансон, який почав займатися нею в 1978 р. в океанаріумі «Світ Океану» у Флориді. Діти 3 відхиленнями в розвитку швидше i краще навчалися різним навичкам, взаємодіючи 3 дельфінами, їх навчання йшло в чотири рази швидше, якщо в якості винагороди за старанність виступала можливість спілкування 3 цією твариною [4]. Спостереження за поведінкою дельфінів під час терапевтичного контакту з людьми показують, що коли людина знаходиться у воді в положенні 
на спині, дельфін розташовується поруч, орієнтуючи ехолокаційному пучок в напрямку голови. На близькій відстані дельфін концентрує ехолокаційний пучок на череп, грудину i хребет пацієнта (кісткова система краще резонує) i використовує повторювані імпульси частотою до 150 кГц, протягом 10--100 мікросекунд до порядку проходження до 600 в секунду. На відстані менше 0,5 м дельфін використовує повторювані кожні 2,5 с імпульси частотою 500 Гц.

Встановлення близького, дружнього контакту 3 дельфіном $є$ передумовою подальшої побудови позитивних i конструктивних відносин 3 оточуючими людьми, дозволяє дитині попрактикуватися в соціальній взаємодії. Спілкування 3 дельфіном є потужним емоційним фактором, який стимулює дитину до освоєння нових рухів і поведінкових патернів, а також робить їі відкритою до сприйняття і закріплення позитивних соціальних установок із боку терапевта. Позитивний емоційний настрій, який відрізняє заняття 3 дельфінами, сприяє піднесенню активності, поліпшенню настрою і загального стану пацієнтів. Гра 3 дельфіном $\epsilon$ стимулом для розвитку психомоторної сфери і різних пізнавальних процесів. Завдяки дельфінам, у пацієнта мобілізується вольова діяльність, зростає мотивація і посилюється прагнення до досягнення позитивних результатів. Тому дитина швидше i ефективніше справляється з ігровими завданнями, які ставить перед нею психотерапевт. Дельфін є стимулом для концентрації уваги дитини, поліпшення процесів пам'яті, мислення й мови. В результаті сеансів дельфінотерапії дитина розширює межі свого світу, набуває нового досвіду спілкування і отримує величезний позитивний психоемоційний заряд.

Фелінотерапія (від латинського felis - кішка) - це метод профілактики i лікування різних захворювань за допомогою особливого роду контактів із кішками. Фелінотерапія заснована, зокрема, на біофізичних ефектах (наявності електростатичного поля вовняного покриву, температури i вібрації),погладжування кішки лівою або правою рукою формує принципово різні латеральні терапевтичні ефекти. Кішки допомагають людині зняти нервову напругу, тому фелінотерапія $є$ корисною при широкому спектрі захворювань: аутизмі, ДЦП, розладах серцево-судинної системи, неврологічних хворобах, безсонні, гіпертонії, ревматизмі тощо. Тихий звук і вібрація муркотіння кішки мають здатність втихомирювати біль [5; 6]. Іноді кішки випускають кігтики i перебирають лапами, роблячи таким чином «лікувальний масаж». Кішки так само позитивно впливають на тривалість життя своїх господарів.

Функції зоотерапії:

•психофізіологічна функція - полягає в тому, що спілкування 3 тваринами здатне рятувати людину від стресу, покращувати роботу нервової системи i психіки в цілому;

•психотерапевтична функція - спілкування з тваринами сприяє гармонізації міжособистісних відносин; 
•реабілітаційна функція - контакти 3 тваринами служать додатковим каналом взаємодії особистості 3 навколишнім світом, сприяють психічній i соціальній реабілітації;

• функція задоволення потреби в компетентності,- виражається формулою "я можу";

•функція самореалізації,- сприяння реалізації людиною свого внутрішнього потенціалу, відчуття значимості для інших;

- функція спілкування.

Втім, зоотерапія, як і будь-який метод, може мати негативні сторони, такі як: можливий прояв агресивності тваринами, алергія, небезпека паразитарних захворювань.

За даними окремих авторів, незважаючи на те, що вплив кішок на нервову систему i психологічний стан людей загалом позитивний, деякі інтернати, будинки для людей похилого віку, наркологічні лікарні все-таки відмовляються від таких мешканців. Пов'язано це, перш за все, з непередбачуваністю кішок, їх деякою відчуженістю («гуляє сама по собі»). Також відзначалися поодинокі випадки агресивного ставлення кішок по відношенню до людей [7]. Тому до анімалотерапії слід залучати не абияких тварин, а лише спеціально відібраних $\mathrm{i}$ підготовлених.

Серйозний привід для занепокоєння представляє загроза алергічних реакцій людей на тварин. Тому завданням зоотерапевта $\epsilon$ обов'язкове з'ясування в пацієнта (або у його батьків) наявності у нього алергічної реакції на конкретну тварину. I якщо все-таки алергія присутня, то варто або відмовитися від терапії, або продовжити, але вже не пряме спілкування, а використання образів тварини (зображень, звуків) [8]. 3 іншого боку, є дані наукових досліджень про те, що контакт iз тваринами в ранньому дитячому віці може бути захисним фактором проти розвитку алергічної сенсибілізації і дитячих алергічних захворювань. У дослідженнях було показано, що в сім'ях фермерів в домашньому пилу і ліжках дітей виявляються більш високі концентрації ендотоксину в порівнянні 3 сім'ями, не пов'язаними 3 тваринництвом. Ендотоксини та інші мікробні складові можуть регулювати такі процеси імунної системи, як продукція інтерлейкіну-12 і інтерферону, що, в свою чергу, призводить до розвитку неатопічної імунної відповіді в ранньому дитячому віці. Також було встановлено, що постійний тривалий контакт із тваринами дітей у віці до 5 років був асоційований з найменшою частотою випадків бронхіальної астми, сінної лихоманки і атопічної сенсибілізації.

Ще один аспект - небезпека паразитарних захворювань. Всі тварини, які залучаються до анімалотерапії, мусять бути обов'язково щеплені і регулярно проходити ветеринарний огляд. Однак імовірність зараження тварин залишається, наприклад при їх контакті 3 іншими тваринами 3 навколишнього середовища [9]. Але при направленому використанні анімалотерапії і правильній роботі зоотерапевта негативні наслідки можна практично виключити. 
Діяльність за участю тварин може бути пасивною або активною. Як приклад першої, можна навести спостереження за тваринами в їх природному середовищі існування. При цьому хворі люди не контактують безпосередньо з тваринами, а отримують відчутну користь для здоров'я просто від їх присутності - наприклад, якщо в реабілітаційних палатах для людей похилого віку є клітини з птахами, то рівень депресії у них знижується. Спілкування з природою, «розчинення в ній» також відноситься до цієї форми спілкування 3 тваринами. При активній діяльності за участі тварин пацієнти грають з ними або за ними доглядають. На противагу просто діяльності, неважливо - активної або пасивної, терапія за участю тварин $є$ цілеспрямованим втручанням, при якому тварина $\epsilon$ повноправним учасником лікувального процесу i від нього багато в чому залежить терапевтичний ефект. Для такої терапії потрібні не тільки спеціально підготовлені тварини, а й особливо навчений персонал. В ідеалі в ній беруть участь тренер або дресирувальник, лікар i психолог. Існує гіпотеза, що електромагнітне випромінювання, властиве будь-якій живій матерії, дозволяє людині і тваринам впливати на інші біологічні об'єкти. При цьому головну роль грає не сила такого випромінювання, а інформація, яка в ньому міститься, тобто спектр його частот. I цей частотний резонанс може стимулювати життєдіяльність організму в досить широкому діапазоні, включаючи психіку людини. Цим i пояснюється той факт, що тварини, зокрема кішки і собаки, роблять помітний позитивний психотерапевтичний вплив на людей [10].

Лікувальні фактори зоотерапії обумовлені ії впливом на канали сприйняття, зокрема [11]:

-Тактильна комунікація. В комунікативній системі людини тактильний канал, звичайно, не має провідного значення. Проте в певних ситуаціях саме тактильна комунікація виступає на перший план і $є$ абсолютно необхідною для нормального розвитку психіки. Тактильна депривація дитини обумовлює дефекти розвитку емоційної і навіть когнітивної сфери, зумовлює невротичні тенденції у формуванні особистості на більш пізніх стадіях онтогенезу. Саме тому тактильна комунікація хворих дітей із собаками, повертаючи їх до витоків, дозволяє проводити досить ефективну корекцію. Особливого значення набуває тактильний канал для сліпих і сліпоглухонімих людей. При цьому значно зростає чутливість, сприйнятливість відповідних сприймають систем, а тактильний канал стає провідним в системі комунікації. Навіть у здорових людей, в результаті спеціального тренінгу, можна розвинути тактильні аналізатори таким чином, що у них різко зростають можливості тактильного спілкування 3 партнерами, з'являється нове джерело отримання сенсорної інформації про інших людей.

-Хімічний канал комунікації. Оскільки нюх людини (а відповідно, i здатність до хімічної комунікації) розвинений відносно слабко, то роль запахів як комунікативних сигналів у людини невелика. Мабуть, з усіх комунікаційних сигналів нюхові сигнали інших тварин найменш доступні як для сприйняття 3 
боку людини, так і декодування, інтерпретації. Люди зазвичай обмежуються поділом природних запахів на «приємні» і «неприємні».

-Візуальний канал комунікації. Невербальна комунікація - невід'ємна і важлива сторона взаємодії людей. На основі інтерпретації невербальної поведінки розкривається внутрішній світ партнера по спілкуванню, здійснюється формування психологічного змісту спілкування та спільної діяльності. Невербальна поведінка виявляється не тільки знаком психічних станів людини, а й способом їх розвитку і формування. При встановленні контактів людини 3 різними тваринами (особливо тими, що ведуть груповий спосіб життя) візуальний канал комунікації виявляється основним.

- Аудіальний канал комунікації. Звукова комунікація - найбільш універсальний тип комунікації, широко поширений, включений в поведінку практично на всіх етапах розвитку тваринного світу, відіграє в поведінці величезну роль. Існує основне розходження між вродженими поведінковими стереотипами вираження, властивими тваринам, і людською мовою як засобом комунікації, придбаним в процесі навчання в онтогенезі, що є матеріалізацією соціального досвіду. Фонетичний лад, граматичні та синтаксичні категорії, лексична безмежність принципово відрізняють мову людини від будь-якої вродженої системи комунікації, якою б складною вона не здавалася на перший погляд і як би не була вона організована по суті.Звукові сигнали тварин в значній мірі можуть бути зрозумілі людині. Особливе значення звукова комунікація має при встановленні контактів 3 такими птахами, як папуги, єдиними істотами, 3 якими людина взагалі здатна «поговорити» на своїй мові. 3 давніх-давен людина намагається впливати на поведінку тварин, імітуючи їх власні звукові сигнали як своїм голосом, так і за допомогою спеціальних пристосувань [12].

Висновки. Отже, взаємодія 3 людини 3 тваринами має глибокий характер, що обумовлює ефективність використання анімалотерапії для лікування різноманітних психологічних i психофізіологічних травм. Основні види взаємодії людини із тваринами систематизовані у Табл.1.

Таблиця 1

\section{Види взасмодії людини із тваринами}

\begin{tabular}{|l|l|}
\hline \multicolumn{1}{|c|}{ Види взаємодії } & \multicolumn{1}{|c|}{ Зміст взаємодії } \\
\hline $\begin{array}{l}\text { Пасивна діяльність за } \\
\text { участю тварин }\end{array}$ & $\begin{array}{l}\text { Терапевтичний ефект досягаєтья шляхом спостереження за } \\
\text { тваринами в штучому або природному середовищі } \\
\text { iснування(рибки в акваріумі, різні види тераріумів, тварини у } \\
\text { вольєрах, відвідування природних парків) }\end{array}$ \\
\hline $\begin{array}{l}\text { Активна діяльність за } \\
\text { участю тварин }\end{array}$ & $\begin{array}{l}\text { Терапевтичний ефект досягається шляхом здійснення активних } \\
\text { дій, у які залучені тварини (гра з тваринами, догляд за тваринами } \\
\text { тощо) }\end{array}$ \\
\hline Терапія за участю тварин & $\begin{array}{l}\text { Терапевтичний ефект досягається через активну взаємодію } \\
\text { людини із твариною як рівноправних партнерів (тварина } є \\
\text { включеною в процес, своєрідним «лікарем») }\end{array}$ \\
\hline
\end{tabular}




\section{Jimepamypa:}

1. Brewin CR. Risk factor effect sizes in PTSD: what this means for intervention. J Trauma Dissociation. 2005;6(2):123-130.

2. CPG (2010). "Підручник по клінічній практиці у поводженні із пост-травматичним стресом." Видання Міністерства у справах Ветеранів та Департаменту оборони США, 2010, 254 с, більше 600 літ.дж. (VA/DoD Clinical Practice Guideline for Management of Post-traumatic Stress, 2010) англ.

3. De Kleine R.A., Rothbaum B.O., van Minnen A. Pharmacological enhancement of exposurebased treatment in PTSD: a qualitative review // Eur J Psychotraumatology.- 17 Oct 2014.- Vol.4. // [Електронний ресурс]. - Режим доступу: http://dx.doi.org/10.3402/ejpt.v4i0.21626.

4. Gurvits TV, Gilbertson MW, Lasko NB, et al. Neurologic soft signs in chronic posttraumatic stress disorder.Arch Gen Psychiatry. Feb 2000;57(2):181-186.

5. Levinson B. M. The dog as a co-therapist / Boris Mayer Levinson.- M.: Mental Hygiene, 1962 // Електронний ресурс.- режим доступу: https://ru.wikipedia.org/wiki/Канистерапия

6. Litz BTWL, Wang J, Bryant R, Engel CC.A therapist-assisted Internet self-help program for traumatic stress. Prof Psychol Res Pr. December 2004;35(6):628-634.

7. Lorenz $K$. Evolution and modification of behavior. Chicago, University of Chicago press, 1965.- pp. 29-48.

8. Milad MR, Quirk GJ. Neurons in medial prefrontal cortex signal memory for fear extinction. Nature. Nov 7 2002;420(6911):70-74.

9. Pichot T., Coulter M. Animal Assisted Brief Therapy: A solution-Focused Approach / Teri Pichot, Marc Coulter.- USA: The Haworth Press, Inc., 2007 // Електронний ресурс.- режим доступу: www.worldcat.org/.../animal-assisted-brief-therapy-a-solutio.

10. Pitman RK, Sanders KM, Zusman RM, et al. Pilot study of secondary prevention of posttraumatic stress disorder with propranolol. Biol Psychiatry. Jan 15 2002;51(2):189-192.

11. Taylor FB, Lowe K, Thompson $C$, et al. Daytime Prazosin Reduces Psychological Distress toTrauma Specific Cues in Civilian Trauma Posttraumatic Stress Disorder. Biol Psychiatry. Feb 32006.

12. Свген Романенко, Л. Помиткіна. ОБГРУНТУВАННЯ ТА МЕТОДИКА ПСИХОКОРЕКЦЙНОЇ ПРОГРАМИ ПРИ СИМПТОМАХ ПОСТТРАВМАТИЧНОГО СТРЕСОВОГО РОЗЛАДУ ІЗ ЗАСТОСУВАННЯМ КАНІС - І ФЕЛІНОТЕРАПІЇ. Науков інновачіï та передові технологї. - № 1(1) 2021. - с. 141-151.

\section{References:}

1. Brewin CR. Risk factor effect sizes in PTSD: what this means for intervention. J Trauma Dissociation. 2005;6(2):123-130.

2. CPG (2010). "Підручник по клінічній практиці у поводженні із пост-травматичним стресом." Видання Міністерства у справах Ветеранів та Департаменту оборони США, 2010, 254 с, більше 600 літ.дж. (VA/DoD Clinical Practice Guideline for Management of Post-traumatic Stress, 2010) англ.

3. De Kleine R.A., Rothbaum B.O., van Minnen A. Pharmacological enhancement of exposurebased treatment in PTSD: a qualitative review // Eur J Psychotraumatology.- 17 Oct 2014.- Vol.4. // [Електронний ресурс]. - Режим доступу: http://dx.doi.org/10.3402/ejpt.v4i0.21626.

4. Gurvits TV, Gilbertson MW, Lasko NB, et al. Neurologic soft signs in chronic posttraumatic stress disorder.Arch Gen Psychiatry. Feb 2000;57(2):181-186.

5. Levinson B. M. The dog as a co-therapist / Boris Mayer Levinson.- M.: Mental Hygiene, 1962 // Електронний ресурс.- режим доступу: https://ru.wikipedia.org/wiki/Канистерапия

6. Litz BTWL, Wang J, Bryant R, Engel CC.A therapist-assisted Internet self-help program for traumatic stress. Prof Psychol Res Pr. December 2004;35(6):628-634. 
7. Lorenz K. Evolution and modification of behavior. Chicago, University of Chicago press, 1965.- pp. 29-48.

8. Milad MR, Quirk GJ. Neurons in medial prefrontal cortex signal memory for fear extinction. Nature. Nov 7 2002;420(6911):70-74.

9. Pichot T., Coulter M. Animal Assisted Brief Therapy: A solution-Focused Approach / Teri Pichot, Marc Coulter.- USA: The Haworth Press, Inc., 2007 // Електронний ресурс.- режим доступу: www.worldcat.org/.../animal-assisted-brief-therapy-a-solutio.

10. Pitman RK, Sanders KM, Zusman RM, et al. Pilot study of secondary prevention of posttraumatic stress disorder with propranolol. Biol Psychiatry. Jan 15 2002;51(2):189-192.

11. Taylor FB, Lowe $K$, Thompson $C$, et al. Daytime Prazosin Reduces Psychological Distress toTrauma Specific Cues in Civilian Trauma Posttraumatic Stress Disorder. Biol Psychiatry. Feb 32006.

10. Evgen, Romanenko \& L., Pomitkina. (2021). OBIRUNTUVANNJa TA METODIKA PSIHOKOREKCIJNOÏ PROGRAMI PRI SIMPTOMAH POSTTRAVMATIChNOGO STRESOVOGO ROZLADU IZ ZASTOSUVANNJaM KANIS - I FELINOTERAPIÏ [RATIONALE AND METHODS OF PSYCHO-CORRECTIONAL PROGRAM FOR SYMPTOMS OF POSTTRAUMATIC STRESS DISORDER WITH THE USE OF CANIS - AND FELI]. Naukovi innovaciï ta peredovi tehnologii Scientific innovations and advanced technologies, 1(1) 2021, 141-151 [in Ukrainian]. 